\title{
Mengurai Paradigma Pemikiran Gerakan Islamisme dan Pos-Islamisme di Era Kontemporer
}

\author{
M. Nur Fauzi \\ Institut Agama Islam Darussalam Banyuwangi, Indonesia \\ fauzinur78@gmail.com
}

\begin{abstract}
This article discusses the paradigm of thought of Islam transnational movement to spread its ideas and discourse in the public sphere. The Islamic transnational movement on this research focused on Islamism and Post Islamism. The research tries to answer a few questions the idea and discourse, shifting paradigm of idea and discourse from Islamism to Post Islamism, and its response to the discourse that grow up from Western civilization. This research founded that it is significant of Islamic shifting paradigm from both Islamic movements. At last, the shifting of the Islamic paradigm caused the differences of thought to respond to the discourse from western modern civilization. From that different paradigm thought of the both contemporary Islamic movement has a result the difference of the product of thought and dichotomic-dualistic too. Islamisms so far reject the ideas and discourse from the Western civilization, meanwhile, Post Islamism more appreciate, accept, and critically.
\end{abstract}

Keywords: Islamism movement, Post Islamism movement, Islamic state, shifting paradigm, authoritarian discours

\begin{abstract}
Abstrak
Artikel ini membahas tentang paradigma pemikiran gerakan Islam transnasional dalam menyebarkan ide dan gagasannya di ruang publik. Gerakan Islam transnasional yang menjadi fokus pembahasan di sini adalah gerakan Islamisme dan Pos-Islamisme. Penelitian ini berupa untuk menjawab beberapa pertanyaan yang terkait dengan ide dan gagasan, serta pergeseran paradigma pemikiran gerakan Islamisme dan PosIslamisme. Dari penelitian ini ditemukan bahwa terdapat pergeseran paradigma pemikiran keislaman yang signifikan dari kedua gerakan Islam ini. Pergeseran pemikiran keislaman ini pada akhirnya menyebabkan pola perbedaan dalam menyikapi wacana dan gagasan yang muncul dari modernitas peradaban Barat. Berangkat dari perbedaan paradigma tersebut, pemikiran kedua gerakan Islam kontemporer ini juga mengarah pada produk pemikiran yang berbeda dan bernuansa dualistik-dikotomik. Islamisme mengarah pada penolakan terhadap wacana, ide, dan gagasan yang lahir dari Barat, sementara Pos-Islamisme sebaliknya, lebih apresiatif dan kritis.
\end{abstract}

Kata Kunci: Islamisme, Pos-Islamisme, negara Islam, otoritas wacana, pergeseran paradigma 


\section{Pendahuluan}

Aksi radikalisme dan terorisme yang terjadi beberapa waktu lalu di Indonesia kian meneguhkan bahwa wacana keagamaan masih menjadi senjata yang ampuh untuk menarik massa demi meraih kepentingan politik dan identitas kelompok tertentu. Menurut Azyumardi Azra pasca runtuhnya ISIS (Islamic State of Irak and Sham/Syria) yang sering diklaim sebagai "khilafah" atau Dawlah Islamiyyah (disingkat dalam bahasa Arab sebagai Da'Is) atau IS, akan memiliki pengaruh signifikan terhadap perdebatan mengenai wacana dan aktivitas kalangan Islamis di Indonesia. ${ }^{1}$

Pasca runtuhnya khilafah Turki Utsmani ${ }^{2}$ pada 1924, umat Islam menghadapi kegalauan yang mendalam ketika berhadapan dengan wacana modernitas seperti privatisasi ruang gerak perempuan, hijabisasi/jilbabisasi di ruang publik, ketaatan rigid dan dogmatik terhadap teks, feminisme, nasionalisme, liberalisme, sekularisme, relasi Islam dan demokrasi, relasi agama dan negara yang dilontarkan oleh peradaban Barat. ${ }^{3}$ Di satu sisi, sebagian menolak secara tegas wacana tersebut, karena berasal dari luar Islam. Kalangan yang kontra terhadap wacana barat ini biasanya disebut dengan aliran atau gerakan Islamisme. Sementara di sisi lain, ada sebagian kalangan Islam yang menerima wacana yang dimunculkan pihak Barat tersebut dengan selektif, apresiatif, dan kritis yang dikenal dengan gerakan Pos-Islamisme.

Mencermati mencuatnya dualisme gerakan Islam tersebut menjadi penting mengingat begitu derasnya arus perubahan yang dibawa oleh globalisasi dan industrialisasi di era kontemporer. Perubahan ini mau tidak mau berpengaruh terhadap pola pandang dan paradigma berpikir umat Islam dalam memandang realitas kehidupan yang demikian kompleks. Kalangan Islamisme yang cenderung tekstualistik-harafiyah dalam mewacanakan pemikirannya, seringkali membelah realitas menjadi hitam-putih, benar-salah, sehingga membuat ruang gerak penafsiran Islam terlihat rigid, kaku dan sempit. Model penafsiran seperti ini, di samping anti realitas, established atau pro kemapanan, juga tidak relevan dengan semangat Islam yang dinamis dan mengusung perubahan demi perbaikan.

\footnotetext{
1 Azyumardi Azra. Transformasi Politik Islam Radikalisme, Khilafatisme, dan Demokrasi. (Jakarta: Prenada Media Group, 2016), 247-260.

${ }^{2}$ Menurut Yudian Wahyudi hilangnya sistem khilafah ini salah satunya adalah karena kalah (losed match) secara militer dalam Perang Dunia 1 (1918). M. Djidin dan Sahiron Syamsuddin, "Indonesian Interpretation of The Qur'an on Khilafah the Case of Quraish Shihab and Yudian Wahyudi on Qur'an 2: 30-38. Al-Jāmi‘ah: Journal of Islamic Studies 57, No. 1 , $(2019$ M/1440 $\mathrm{H})$, https://doi.org/10.14421/ajis.2019.57

3 Nugraha, Muhammad Tisna. "Fundamentalisme Pendidikan Agama di Jejaring Sosial". AlTahrir: Jurnal Pemikiran Islam 18, No. 1, (2018), https://doi.org/10.21154/altahrir.v18i1.1172 
Jika semangat dan paradigma Islamisme yang mengemuka maka Islam akan semakin tenggelam di tengah ramainya peradaban besar dunia saat ini. Islam tidak akan mampu menunjukkan semangat dan spirit perubahan karena kebesarannya tertutupi dengan kepentingan sesaat dari segelintir umat (Al-Islam mahjubun bi al-muslimin) yang berpaham tertutup, eksklusif dan anti perubahan. Realitas keberagamaan umat di era kontemporer yang plural dan bahkan multikultural ini membutuhkan pemahaman keislaman yang dinamis, fresh, dan relevan dengan kondisi kekinian. Menurut M. Amin Abdullah, memahami Islam tidak bisa dengan hanya satu disiplin keilmuan saja, tetapi harus melalui multidisiplin, interdisiplin, dan transdisiplin keilmuan sehingga akan didapatkan pemaknaan Islam yang kompatibel, aktual dan sesuai dengan semangat zamannya. ${ }^{4}$ Inilah yang coba ditawarkan oleh kalangan atau gerakan Pos-Islamisme sebagai bentuk pengayaan pemikiran akibat persinggungan dengan wacana modernitas yang diusung oleh peradaban Barat.

Berbasis analisis historis kritis-komparatif artikel ini berupaya mengungkap pergeseran ide, gagasan, dan aksi kalangan Islamisme dan Pos-Islamisme dalam merespons isu-isu kekinian. Pergeseran ini terlihat dari arus pemikiran yang diusung oleh kalangan Islamis yang tidak hanya berbenturan dengan wacana modernitas yang berasal dari Barat, tetapi juga berhadapan dengan ide dan pemikiran yang digagas oleh kalangan Islam mainstream di Indonesia. Di sinilah terlihat nilai signifikansi dan urgensitas dari penelitian ini.

\section{Metode}

Artikel ini merupakan penelitian kepustakaan (library research) yang bercorak faktual historis dan kontekstual. Paradigma yang digunakan dalam penelitian ini adalah paradigma kualitatif. Pengumpulan data dilakukan dengan menggunakan library research data yang mengandalkan atau memakai sumber kepustakaan. Penelitian pustaka ini berasal dari sumber primer dan sekunder yang terdapat di berbagai bukubuku dan artikel-artikel jurnal penelitian yang terbit di website yang terkait dengan penelitian. Sumber-sumber data ini kemudian dianalisis dengan jalan membaca dan menelaah buku-buku dan artikel yang berkaitan dengan tema penelitian ini. Analisis data dalam penelitian ini dengan menggunakan analisis isi atau wacana (content

${ }^{4}$ M. Amin Abdullah, Multidisiplin, Interdisiplin, dan Transdisiplin Metode Studi Agama dan Studi Islam di Era Kontemporer (Yogyakarta: IB Pustaka PT Litera Cahaya Bangsa-Pusat Studi Perubahan Sosial Universitas Muhammadiyah Surakarta, 2020), 97.

Tribakti: Jurnal Pemikiran Keislaman

Volume 32, Nomor 1, Januari 2021 
analysis) dengan mencermati berbagai data yang telah dikumpulkan. Dari pembacaan terhadap berbagai referensi tersebut penulis analisis secara kritis-komparatif sehingga memunculkan temuan baru yang relevan dengan konteks kekinian.

Sementara itu alasan yang mendasari mengapa penelitian ini menjadi penting adalah karena kondisi keberagamaan umat di era kontemporer ini semakin tidak menentu dengan munculnya aliran-aliran yang mengklaim sebagai pemilik kebenaran tunggal dan menafikan pihak-pihak lain yang berbeda dengannya. Situasi seperti ini membuat kondisi keberagamaan umat menjadi tidak sehat dan tumbuh saling curiga dan menyalahkan satu sama lain. Oleh karena itu diperlukan upaya pembongkaran terhadap model dan cara berpikir dari sebagian kalangan yang mengklaim memiliki kebenaran tunggal tersebut sehingga didapatkan satu pemahaman keislaman yang inklusif dan moderat.

\section{Hasil dan Pembahasan}

\section{Islam Transnasional: Tren Islamisme dan Pos-Islamisme}

Menurut Masdar Hilmy istilah gerakan Islam transnasional dimunculkan pertama kali oleh Syafi'i Ma'arif dan K.H. Hasyim Muzadi. Istilah Islam transnasional digunakan untuk menyebut kelompok islamis yang membawa misi transformasi sosial keagamaan secara radikal yang bersifat melintasi batas-batas nasionalisme keindonesiaan. Dalam pandangan Hilmy, konsep Islam transnasional terdiri dari tiga hal: 1) pergerakan demografis, dengan terjadinya mobilitas yang dilakukan oleh orang per-orang dan atau kelompok dari satu negara ke negara lainnya, 2) lembaga keagamaan transnasional, yang menyediakan jejaring antar lembaga keagamaan di sejumlah tempat atau negara; dan 3) perpindahan gagasan atau ide, yang melihat modus pergerakan atau perpindahan gagasan dari individu atau sekelompok individu di sebuah tempat atau negara ke individu atau sekelompok individu di negara lain. Ketiga hal tersebut terjadi seiring dengan tren globalisasi dan maraknya teknologi informasi yang sangat masif. ${ }^{5}$

Menurut Edward W. Said sebagaimana dikutip Hilmy, perpindahan gagasan dari satu tempat ke tempat lain terjadi melalui empat tahapan: pertama, a point of origin atau lokasi asal di mana seperangkat gagasan tercetus, dielaborasi, atau dikontestasikan dalam ruang wacana di tempat asal; kedua tahap distance transversed yang terjadi saat sebuah ide mengalami perjalanan dari satu tempat ke ruang dan waktu yang berbeda;

${ }^{5}$ Masdar Hilmy, “Akar-akar Transnasionalisme Islam Hizbut Tahrir Indonesia (HTI)”. Islamica: 6, No. 1, (2011) 
ketiga tahap encounter stage yang terjadi ketika gagasan tersebut bertemu dengan gagasan atau ideologi lain serta dikontestasikan dalam sebuah ruang wacana yang bisa berujung pada sebuah penerimaan, penolakan, modifikasi, dan adaptasi; dan yang keempat adalah tahap "transformasi" di mana gagasan tersebut menjelma menjadi sebuah entitas baru yang diterima oleh pihak penerima. ${ }^{6}$

Dalam perspektif kesejarahan proses transmisi gerakan Islam transnasional sesungguhnya telah terjadi sejak dahulu kala melalui jaringan ulama yang terbentuk pada abad ke 17-18 M. Jaringan itulah yang kemudian memberikan inspirasi kepada organisasi-organisasi Islam di Indonesia Sarikat Islam (SI)/ Sarikat Dagang Islam, Jamiat Khair, al-Irsyad, Muhammadiyah, Nahdlatul Ulama (NU), Persatuan Islam, dan lain-lainnya. Sementara gerakan-gerakan Islam baru seperti Gerakan Tarbiyah dan Hizbut Tahrir Indonesia mulai popular di beberapa kota besar di Indonesia pada dekade 1980-an, melalui, salah satunya, dengan maraknya penerjemahan buku-buku Yusuf Qardawi, Hasan al-Banna, Sayyid Qutb, Sa'id al-Hawwa, Muhammad al-Ghazali, Taqiy al-Din al-Nabhani, dan Nashir al-Din al-Bani. ${ }^{7}$

Dalam perjalanan sejarahnya, penafsiran terhadap Islam memang tidak tunggal, tetapi sebaliknya, terjadi heterogenitas pemaknaan secara faktual di ranah praksisnya. Di satu sisi, ada kalangan yang memaknai Islam sebagai agama yang membawa misi perdamaian, mengedepankan nilai-nilai kemanusiaan universal dan perbaikan moralitas peradaban dan dunia. Sementara di sisi lain terdapat segolongan orang yang menafsirkan Islam secara ideologis-teologis dan menyeret Islam dalam kubangan politik yang sarat dengan berbagai kepentingan sesaat dan profan. Kelompok terakhir inilah yang biasa dikenal dengan kalangan Islamisme. ${ }^{8}$

Di Mesir misalnya, perdebatan yang paling mengemuka terjadi antara kelompok Islamis yang mengusung formalisasi syariat Islam dengan kelompok sekuler yang mengusung pemisahan agama dan negara. Perdebatan bermula sejak tahun 1925, ketika Ali Abdul Raziq menerbitkan buku, Al-Islām wa Ușūl Al-Hukm (Islam dan Prinsip-

${ }^{6}$ Hilmy, "Akar-akar Transnasionalisme Islam. Said meyakini bahwa teks tidaklah berbicara di dalam makna yang biasa dari kata tersebut. Namun, oposisi diametrik sesederhana apa pun menegaskan pada satu sisi antara ujaran (speech) yang terikat oleh situasi, dan referensi, serta pada sisi lain teks sebagai pintasan atau suspensi (penundaan) dari keduniawian teks. Lihat Edward Said, Dunia, Teks, dan (Sang) Kritikus, Terjemahan oleh Sunaryono Basuki Ks (Bali: Bali Media Adhikarsa, 2012), 40.

${ }^{7}$ Ahmad Khoirul Fata dan Moh Nur Ikhwan "Pertarungan Kuasa dalam Wacana Islam Nusantara". Islamica: Jurnal Studi Keislaman 11. No. 2. (2017), https://doi.org/10.21154/.v16i2.554

${ }^{8}$ Ayang Utriza Yakin, "Salafi Dakwah and the Dissemination of Islamic Puritanism in Indonesia: A Case Study of the Radio of Rodja". Ulumuna: Journal of Islamic Studies 22, No. 2, (2018), https://doi.org/10.20414/ujis.v22i2.335

Tribakti: Jurnal Pemikiran Keislaman

Volume 32, Nomor 1, Januari 2021 
Prinsip Pemerintahan). Abdul Raziq adalah seorang ulama al-Azhar, yang menjabat sebagai hakim di pengadilan agama. Di dalam karyanya, Ali Abdul Raziq secara eksplisit menentang dan menolak sistem khilafah untuk diterapkan kembali di dunia Islam pasca-jatuhnya Dinasti Utsmani di Turki. Raziq menyatakan, "pemerintahan dalam negara Islam bisa dengan berbagai sistem: absolut atau terbuka, monarki atau republik, otoriter, konstitusional, demokratis, sosialis, dan bolshevik." Pandangan ini membuktikan, pemerintahan ala khilafah sudah tidak relevan lagi, karena Dinasti Utsmani sudah berakhir sejak tahun 1923. Turki memilih sekularisme sebagai salah satu sistem pemerintahan pasca-jatuhnya sistem khilafah. ${ }^{9}$

Abdurrahman Wahid (Gus Dur) menegaskan tidak ada teks yang secara eksplisit mengarah pada upaya penegakan institusi khilafah atau negara Islam. Menurutnya para pengusung gagasan khilafah seringkali menggunakan ayat-ayat Tuhan secara sepotongsepotong, parsial dan menyerabut dari konteks atau sisi historisitas yang melingkupinya. ${ }^{10}$ Senada dengan Gus Dur, Nadirsyah Hosen mensinyalir teks-teks yang mengarah pada penegakan khilafah telah dipelintir dan sangat bernuansa dengan kepentingan politik tertentu. ${ }^{11}$

Mujamil Qomar mensinyalir pro dan kontra terkait isu khilafah selalu up date dan membuat energi umat Islam terkuras dalam perdebatan yang hampir tak kunjung usai. ${ }^{12}$ Bagi sebagian kalangan yang mendukung konsep ini, khilafah merupakan bagian dari ajaran Islam yang paling asasi dan pokok yang harus diperjuangkan dengan berbagai macam cara dan jalan. Bila jalan damai tak mungkin, aksi kekerasan tak jarang ditempuh untuk mewujudkannya. ${ }^{13}$ Khilafah tidak kebal terhadap evolusi hukum sejarah yang berproses secara dialektis. ${ }^{14}$

\footnotetext{
${ }^{9}$ Komaruddin Hidayat dkk. Kontroversi Khilafah Islam, Negara dan Pancasila (Bandung: Mizan, 2014), 78.

${ }^{10}$ Abdurrahman Wahid, Islamku Islam Anda Islam Kita Agama Masyarakat Negara Demokrasi (Jakarta: The Wahid Institute, 2006), hlm. 12-16. Abdurrahman Wahid, Ilusi Negara Islam Ekspnasi Gerakan Transnasional di Indonesia (Jakarta: Gerakan Bhinneka Tunggal Ika, The Wahid Institute, Maarif Institute, 2009), 17.

${ }^{11}$ Hidayat (ed.). Kontroversi Khilafah Islam, 152.

12 Mujamil Qomar, Fajar Baru Islam Indonesia? Kajian Komprehensif atas Arah Sejarah dan Dinamika Intelektual Islam Nusantara (Bandung: Mizan, 2012), 129-132.

${ }^{13}$ Kekerasan dengan mengatasnamakan agama seringkali digunakan untuk melegitimasi tindakan individu atau kelompok dalam mewujudkan keinginan dan tujuan-tujuan politik tertentu. Pernyataan ini senada dengan pertanyaan Marx Juergensmeyer, Mark Juergensmeyer, Teror dan Tuhan, dalam Thomas Santoso Kekerasan Agama Tanpa Agama, (Jakarta: Pustaka Utan Kayu, 2002), 47.

14 Ridwan Rosdiawan, "Memetakan Anatomi Diskursus Islamisme dan Terorisme Islam". Islamica: Jurnal Studi Keislaman 13, No. 1, (2018), https://doi.org/10.21154/.v16i2.554 
Oleh karena itu resurgensi khilafah dalam panggung sejarah peradaban umat menjadi salah satu kewajiban dan agenda untuk diperjuangkan. Upaya ini pernah coba dilakukan oleh Syaikh Taqiyy al-Dīn al-Nabhāni dengan mendirikan Hizb al-Tahrīr (Partai Pembebasan) di Suriah pada tahun 1953. Partai ini mengusung misi menegakkan kembali negara khilafah Islam di muka bumi. Al-Nabhāni mendirikan partai ini sebagai wadah perjuangan menuju tegaknya kembali negara khilafah. Awalnya partai ini menargetkan 13 tahun untuk lahirnya negara khilafah baru di era modern. Tetapi masa itu pun berlalu, sementara negara yang dicita-citakannya tak kunjung berdiri. Akhirnya ia menargetkannya kembali dalam kurun waktu tiga dasawarsa. Tetapi hingga saat ini pun tak satu negara pun diproklamirkan sebagai negara khilafah. ${ }^{15}$

Tak jarang para pemikir Barat seperti Oliver Roy yang menuding upaya menghidupkan kembali ide khilafah sebagai sebuah ilusi dalam bernegara. ${ }^{16}$ Senada dengan Roy, Luthfi Asy Syaukani menyebut khilafah sebagai gagasan utopis yang absurd. ${ }^{17}$ Al-Makin menegaskan tentang perlunya menanggalkan wacana khilafah dari bumi kemanusiaan karena sangat kontradiktif dan kontra produktif dengan situasi kekinian yang serba plural dan multikultural yang menghendaki adanya balancing system dalam sistem perpolitikan kontemporer. ${ }^{18}$

Sementara itu, Arab Saudi merupakan sebuah pemandangan yang menarik dalam mencermati salah satu potret Islamisme, yang secara eksplisit tidak kompatibel dengan demokrasi. Arab Saudi merupakan salah satu contoh, dengan syariat Islam sebagai konstitusi, yang mandatnya diberikan kepada Raja dan lembaga fatwa keagamaan untuk memaksakan kepada setiap warganya. Arab Saudi merupakan negara yang menerapkan hukum Islam secara penuh dan menolak konvensi hak asasi manusia. Berbeda dengan Arab Saudi, Mesir relatif mengalami transformasi yang menarik perihal upaya untuk mempertemukan antara Islamisme dan demokrasi. Pasca-tumbangnya rezim Hosni Mubarak, Ikhwan al-Muslimin tumbuh sebagai kekuatan yang hendak memberikan

15 Zainul Mu'ien Husni, "NU di Tengah Pusaran Ideologi-Ideologi Transnasional”. Jurnal Islam Nusantara 02 No. 01, Januari-Juni (2018)

${ }^{16}$ Oliver Roy mencirikan upaya untuk mengkonkritkan "ilusi” tentang negara Islam sebagai "tidak jelas juntrungannya". Dia mendasarkan penilaiannya itu pada bangkrutnya intelektualitas ahli-ahli Islam (Islamis) kontemporer dalam menghadapi tantangan masyarakat modern. Dia memandang bahwa mereka bahkan tidak memiliki solusi terhadap masalah-masalah keseharian yang dominan"kesengasaraan, ketidakberakaran, krisis nilai dan identitas, runtuhnya sistem pendidikan, antagonisme Utara-Selatan, dan masalah-masalah integrasi kaum pinggiran ke dalam masyarakat tuan rumahnya". Dale F. Eickelman dan James Piscatori, Ekspresi Politik Muslim, terjemahan oleh Rofik Suhud (Bandung: Mizan, 1998), 44.

${ }^{17}$ Luthfi Asy Syaukani, Islam Benar versus Islam Salah (Jakarta: Kata Kita, 2007), 215.

18 Al-Makin. "Tanggalkan Khilafah di Bumi Ini: Membaca Narasi Sukarno tentang Sekularisme Turki”. Al-Tahrir: Jurnal Pemikiran Islam 16, No. 2, (2016), https://doi.org/10.21154/al-tahrir.v16i2.554 Tribakti: Jurnal Pemikiran Keislaman Volume 32, Nomor 1, Januari 2021 
warna lain terhadap demokrasi. Ikhwan al-Muslimin merupakan sebuah paradigma baru, yaitu negara modern dengan menjadikan Islam sebagai rujukannya (al-dawlah almadaniyyah bi al-marja'iyyah al-Islamiyyah). Harus diakui, paradigma politik ini telah mengalami metamorfosis dari paradigma politik yang dikembangkan oleh Hasan alBanna sebagai pendiri Ikhwan al-Muslimin. ${ }^{19}$

Munculnya kalangan Islamis ini menimbulkan letupan dan dampak yang tidak kecil terhadap makna Islam itu sendiri. Dalam konteks Indonesia, kalangan Islamis memang tidak bisa dipisahkan dari aktivitas politik dalam dakwah dan perjuangan mendakwahkan Islam. ${ }^{20}$ Jajang Jahroni menggambarkan dengan detail tentang alur sejarah proses dakwah kalangan Islamis di Surakarta, Solo, Yogyakarta (Jawa Tengah hingga Malang dan Surabaya (Jawa Timur) yang berafiliasi dengan al-Irshad dengan segala varian pendidikan dan model dakwahnya. ${ }^{21}$ Dari sinilah sebagian intelektual Islam kontemporer menilai perlunya perbedaan pemaknaan yang tegas antara Islam dan aktivisme Islam. Salah satu bentuk riil aktivisme politik yang membawa nama dan simbol Islam adalah "Parade Tauhid" yang diinisiasi oleh beberapa ormas kalang Islamisme seperti KAMMI, MMI, FPI, HTI, Tarbiyah, LUIS dan MTA beberapa tahun lalu. ${ }^{22}$ Dalam memperjuangkan agenda politiknya mereka seringkali mengerek bendera Islam untuk mencapai tujuannya. Dalam konteks ini perlu dibedakan antara Islam dan Islamisme. Antara Islam sebagai agama dan Islamisme sebagai agenda politik.

Dalam bukunya Islam and Islamism, Bassam Tibi membuat garis demarkasi dan perbedaan yang tegas antara Islam dan Islamisme. Menurutnya, Islamisme terkait dengan tatanan politik, bukan iman. Meski demikian, Islamisme bukanlah semata politik, tetapi politik yang diagamaisasikan. Dalam konteks ini, Tibi menyebut Islamisme sebagai contoh paling kuat dari fenomena global fundamentalisme religius. Dalam perkara Islamisme, agamaisasi politik berarti promosi suatu tatanan politik yang dipercaya beremanasi dari kehendak Allah dan bukan berdasarkan kedaulatan rakyat. Sementara Islam itu sendiri tidak melakukan hal seperti ini. Sebagai iman, cara

\footnotetext{
${ }^{19}$ Syamsul Arifin, Studi Islam Kontemporer Arus Radikalisasi dan Multikulturalisme di Indonesia (Malang: Intrans Publishing, 2015), 92.

20 Redjosari, Slamet Muliono. "Salafi dan Stigma Sesat-Radikal". Islamica: Jurnal Studi Keislaman 13, No. 2, Maret (2019)

${ }^{21}$ Jajang Jahroni, "Saudi Arabia Charity and the Institutionalization of Indonesian Salafism". Al-

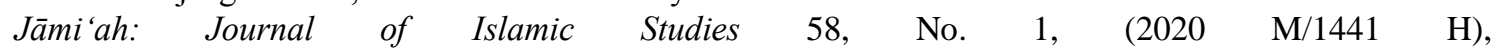
https://doi.org/10.14421/ajis.2018.562.421-460

${ }^{22}$ Muhammad Najib Azca; Hakimul Ikhwan; Moh Zaki Arrobi. "A Tale of Two Royal Cities: The Narratives of Islamists' Intolerance in Yogyakarta and Solo”. Al-Jāmi 'ah: Journal of Islamic Studies 57, No. 1 (2019 M/1440 H) https://doi.org/10.14421/ajis.2018.562.421-460
} 
beribadah dan kerangka etis, Islam menyiratkan nilai-nilai politis tertentu namun tidak mensyaratkan suatu tata pemerintahan khusus. ${ }^{23}$

Tesis Bassam Tibi tersebut dikuatkan oleh Aksin Wijaya. Menurut Aksin ada perbedaan mendasar antara Islam dengan pemikiran Islam. Islam adalah respon Ilahi terhadap realitas melalui Nabi Muhammad, sedangkan pemikiran Islam adalah respons manusia (intelektual muslim atau ulama) terhadap realitas melalui al-Qur'an dan hadis Nabi. Islam pada dirinya hanya ada pada Tuhan semata, bersifat absolut, autentik, universal dan tidak mengalami perubahan sepanjang waktu. Sebaliknya, pemikiran Islam berhubungan dengan manusia, bersifat relatif, subyektif, partikular dan mengalami perubahan dari waktu ke waktu. Islam sebagai agama bersifat tunggal karena berasal dari Yang Maha Tunggal, sedangkan pemikiran slam beragam karena lahir dari manusia yang beragam. Karena itu, muncul beragam pemikiran Islam. ${ }^{24}$

Sementara itu Asef Bayat dalam bukunya Making Islam Democratic: Social Movements and Post-Islamist Turn menyuguhkan gambaran tentang pergeseran paradigma pemikiran Islam politik dalam merespons modernitas Barat yang merasuk ke jantung pertahanan umat Islam dalam setting sosial politik Iran dan Mesir. Sebagai fenomena historis, Islamisme kontemporer merupakan sebuah gerakan dan wacana yang disinyalir telah muncul sejak tahun 1970-an. Menurut Bayat gerakan Islamisme muncul sebagai bahasa penegasan diri untuk memobilisasi masyarakat (kebanyakan kelas menengah) yang merasa termarginalkan oleh proses-proses ekonomi, politik atau budaya dominan dalam masyarakatnya; masyarakat yang merasakan kegagalan modernitas kapitalis maupun utopis sosialis yang kemudian membuat bahasa moralitas melalui agama dan menginginkan pergantian sistem politik. Gerakan Islamisme memiliki beberapa misi yakni: pertama, Islamisme mencoba mengartikulasikan sebuah versi Islam yang dapat merespon defisit politik, ekonomi, dan budaya mereka; kedua, Islamisme membayangkan Islam sebagai sebuah sistem ketuhanan yang lengkap dengan model politik, kode budaya, struktur hukum, dan tata ekonomi yang superior. ${ }^{25}$

\section{Tabel 1}

\footnotetext{
${ }^{23}$ Bassam Tibi, Islam dan Islamisme, Terjemahan oleh Alfathri Adlin (Bandung: Mizan, 2016), 1.

${ }^{24}$ Aksin Wijaya, Kontestasi Merebut Kebenaran Islam di Indonesia dari Berislam secara Teologis ke Berisalam secara Humanis (Yogyakarta: IRCiSoD, 2019), 52.

${ }^{25}$ Asef Bayat, Pos-Islamisme, Terjemahan oleh. Faiz Tajul Milah (Yogyakarta: LKiS, 2011), 12.

Tribakti: Jurnal Pemikiran Keislaman

Volume 32, Nomor 1, Januari 2021
} 


\section{Potret Gerakan Islamisme ${ }^{26}$}

\begin{tabular}{cl}
\hline Ideologi & \multicolumn{1}{c}{ Islamisme } \\
\hline Penggerak & $\begin{array}{l}\text { Pegawai negeri, mahasiswa, profesional, dan cendekiawan muslim } \\
\text { (masyarakat lapisan menengah) }\end{array}$ \\
Jargon & $\begin{array}{l}\text { Al-Islam huwa al-Hal } \\
\text { (Islam adalah solusi) }\end{array}$ \\
Misi & - Islam yang dapat merespon defisit politik, ekonomi, dan budaya \\
& mereka. \\
& - Islam sebagai sistem ketuhanan yang lengkap dengan model politik, \\
& kode budaya, struktur hukum, dan tata ekonomi yang superior. \\
& - Islam yang merespons semua permasalahan manusia dengan rasa \\
& hormat dan percaya diri, serta kemandirian dan kebebasan dalam \\
& banyak hal. \\
Negara & Mesir dan Iran
\end{tabular}

Corak pemaknaan Islam model gerakan Islamisme itu sendiri mendapat tantangan serius dari kalangan intelektual yang disebut dengan Pos-Islamisme. Sejumlah telaah ulang terhadap berbagai konsep kalangan Islamisme atau fundamentalisme pun mengemuka di ruang publik. Menurut Asef Bayat gerakan Pos-Islamisme ${ }^{27}$ pertama muncul di Iran yang dicirikan dengan artikulasi tren-tren sosial yang dominan, perspektif politik, dan rekonstruksi pemikiran keagamaan yang relevan dengan kondisi pada masa itu. Gerakan Pos-Islamisme ini kemudian memuncak ke dalam "gerakan reformasi" akhir tahun 1990-an. Meski murni lahir dalam setting sosial Republik Islam Iran, dan tidak pada latar sosial masyarakat yang lain, tetapi spirit intinya merujuk pada metamorfosis Islamisme (dalam ide, pendekatan, dan praktik), baik secara eksternal maupun internal. ${ }^{28}$

Dalam perdebatan di tingkat global, istilah Pos-Islamisme juga digunakan oleh pemikir Barat misalnya Gilles Kepel. Kepel menggambarkan Pos-Islamisme sebagai keterpisahan Islamisme dari doktrin-doktrin kelompok jihad dan salafi (konservatif dan liberal). Sementara itu, Oliver Roy memahaminya sebagai sebuah "privatisasi" dari

${ }^{26}$ Format tabel merupakan olahan penulis berdasarkan beberapa karya berikut: (1) Asef Bayat, Pos-Islamisme, terjemahan oleh Faiz Tajul Milah (Yogyakarta: LKiS, 2011), (2) David Sagiv, Islam, Otentisitas Liberalisme terjemahan oleh Yudian W. Asmin (Yogyakarta: LKiS, 1997), (3) John L. Esposito, Masa Depan Islam Antara Tantangan Kemajemukan dan Benturan dengan Barat, terjemahan oleh Eva Y. Nukman dan Edi Wahyu SM (Bandung: Mizan, 2010) dan (4) Haedar Nashir, Islam Syariat Reproduksi Salafiyah Ideologis di Indonesia (Bandung: Mizan, 2013).

${ }^{27}$ Istilah Pos-Islamisme dikenalkan di ranah publik oleh Asef Bayat. Menurutnya istilah tersebut berasal dari esai pendek yang ditulisnya yang berjudul "Munculnya Masyarakat Pos-Islamisme". Esai ini ditulis pada tahun 1996 dengan judul "The Coming of a Post-Islamist Society".

${ }^{28}$ Bayat, Pos-Islamisme, 17-18. 
Islamisasi (sebagaimana dipertentangkan kepada Islamisasi negara) di mana penekanannya diletakkan bagaimana dan di mana Islamisasi terjadi, melebihi isinya. ${ }^{29}$

Dalam pandangan Bayat sendiri Pos-Islamisme mewakili satu master (multidimensi) gerakan dan merujuk pada kondisi sosial dan politik sebagai fase eksperimentasi. Bukan hanya satu kondisi, pos-Islamisme juga sebuah proyek, sebuah upaya sadar untuk membangun konsep rasionalitas dan modalitas secara strategis untuk membatasi gerakan Islamisme di area sosial, politik, dan intelektual. Tetapi PosIslamisme tidak anti Islam ataupun sekuler, ataupun non-Islam. Lebih dari itu, ia mewakili upaya untuk meleburkan keagamaan dan hak, iman dan pembebasan, Islam dan kebebasan. Pos-Islamisme berjuang menjunjung pluralitas dari dera suara otoritatif tunggal, menegaskan kesejarahan kitab suci, mensinergikan Islam dengan pilihan dan kebebasan individu, demokrasi dan modernitas. Perjuangan ini mereka sebut sebagai upaya mewujudkan sebuah "modernitas alternatif". 30

Gerakan Pos-Islamisme mengkritik Revolusi Islam Iran yang mengalami kevakuman dari teori (sosial). Mereka mencermati fanatisme keagamaan yang diasyikkan dengan Tuhan, tetapi mengabaikan manusia, dan sebaliknya para intelektual sekuler yang fokus pada manusia saja dan mengabaikan Tuhan. Menurut kalangan ini, intelektual agama tidak hanya "menghormati nalar dan menghargai kebebasan," tetapi juga memahami tubuh lebih dari semata-mata benda dan manusia lebih besar dari semata-mata alam. Mereka tidak mengabaikan, baik ketuhanan maupun manusia, tetapi mengambil "manusia ketuhanan" (insan khuda'i), manusia dengan hak-hak, sebagai titik tolaknya. Nalar, hak-hak dan agama menjadi unsur-unsur fundamental dalam wacana para pemikir ini. Inti kelompok ini berasal dari kelompok menengah, revolusi dunia ketiga, dan yang lebih penting, latar belakang Islamisme. Gerakan Pos-Islamisme banyak dipengaruhi oleh pemikiran modernis Islam Ali Syari’ati, Murtadla Muthahhari, dan Ayatollah Khomeini. Para penggerak utama gerakan Pos-Islamisme di antaranya adalah Muhammad Khatami, presiden pemerintahan reformasi Iran pasca Revolusi Islam yang juga mantan anggota parlemen (1980-1982), dan menteri kebudayaan (19821989), Abdul Karim Soroush, seorang ideolog awal dari negara Islam, dan anggota

${ }^{29}$ Bayat, Pos-Islamisme, 18.

${ }^{30}$ Bayat, 20.

Tribakti: Jurnal Pemikiran Keislaman

Volume 32, Nomor 1, Januari 2021 
Dewan Revolusi Kebudayaan (yang di awal 1980-an berencana mengislamkan kampuskampus dan sistem pendidikan). ${ }^{31}$

\section{Tabel 2}

\section{Potret Gerakan dan Wacana Pos-Islamisme ${ }^{32}$}

\begin{tabular}{ll}
\hline Ideologi & Pos-Islamisme \\
Penggerak & Intelektual muslim, feminis, mahasiswa \\
Jargon & Islam relevan dengan konteks kekinian \\
Wacana & Islam kompatibel dengan modernitas dan nilai-nilai derivatifnya, \\
& nation-state, demokrasi, feminisme dan sebagainya \\
Negara & Iran, Mesir, Turki, dan Tunisia \\
\hline
\end{tabular}

\section{Diseminasi Wacana dan Problem Otoritas}

Dari analisis historis di atas dapat ditelusuri nalar pemikiran yang dikembangkan oleh gerakan Islam transnasional yang direpresentasikan oleh kalangan Islamisme dan Pos-Islamisme. Nalar pemikiran tersebut dapat dicermati dari model perdebatan wacana yang dilontarkan di ranah praksis sosial keagamaan.

Perdebatan paling hangat dan menarik di kalangan Islamisme dan Pos-Islamisme adalah megenai relasi agama dan negara. ${ }^{33}$ Terkait hal ini menurut Zuhairi Misrawi, terdapat tiga pandangan yang mengemuka: pertama, formalistik. Pandangan ini menegaskan bahwa antara keduanya harus menyatu dan tidak bisa dipisahkan. Alasan yang digunakan, karena Nabi Muhammad SAW ketika berada di Madinah sudah mendirikan negara, yang ditandai dengan adanya konstitusi yang menjamin kemajemukan agama dan suku. Nabi tidak hanya menjadi pemimpin agama, tetapi juga sebagai pemimpin politik. Kedua, sekularistik. Pandangan ini menyatakan bahwa relasi antara agama dan negara harus dipisahkan, karena belajar dari pengalaman negaranegara Barat dan Kristiani yang kerap kali menjadikan agama sebagai alat justifikasi

${ }^{31}$ Bayat, Pos-Islamisme, hlm. 156. Pemikiran liberal Abdul Karim Soroush dalam merespons isuisu global di Iran dapat dicermati dalam Mahmoud Sadri dan Ahmad Sadri (eds.), Abdul Karim Soroush Menggugat Otoritas dan Tradisi Agama, Terjemahan oleh Abdullah Ali (Bandung: Mizan, 2002).

${ }^{32}$ Format tabel merupakan olahan penulis berdasarkan beberapa karya berikut: (1) Asef Bayat, Pos-Islamisme, terjemahan oleh Faiz Tajul Milah (Yogyakarta: LKiS, 2011), (2) David Sagiv, Islam, Otentisitas Liberalisme terjemahan oleh Yudian W. Asmin (Yogyakarta: LKiS, 1997), (3) John L. Esposito, Unholy War Teror Atas Nama Islam, terjemahan oleh Safruddin Hasani (Yogyakarta: Ikon Teralitera, 2003), (4) Haedar Nashir, Islam Syariat Reproduksi Salafiyah Ideologis di Indonesia (Bandung: Mizan, 2013), (5) Issa J. Boullata, Dekonstruksi Tradisi Gelegar Pemikiran Arab Islam terjemahan oleh Imam Khoiri (Yogyakarta: LKiS, 2001), (6) Shalahuddin Jursyi, Membumikan Islam Progresif terjemahan oleh M. Aunul Abied Shah (Jakarta: Paramadina, 2004), dan (7) Youssef M. Choueiri, Islam Garis Keras Melacak Akar Gerakan Fundamentalisme terjemahan oleh Humaidi Syuhud dan M. Maufur (Yogyakarta: Qonun, 2003).

${ }^{33}$ Abd. Halim, Relasi Islam Politik dan Kekuasaan (Yogyakarta: LKiS, 2013), 37. 
untuk membenarkan kekerasan serta mendorong konflik. Pengalaman inkuisisi di dalam tradisi Kristiani dan tradisi Islam memberikan pelajaran yang sangat berharga, bahwa agama dan negara harus dipisahkan. Ketiga, komplementaristik. Pandangan ini menegaskan bahwa relasi agama dan negara saling menyempurnakan. Keduanya tidak serta merta dipersatukan atau dipisahkan, melainkan saling melengkapi. Agama dan negara merupakan dua entitas yang saling memengaruhi, terutama dalam rangka mencapai cita-cita ideal universal keduanya. Pandangan ini lebih memaknai agama secara substansialistik. ${ }^{34}$

Bercermin dari pandangan di atas, gerakan Islamisme dapat dikategorikan pada tingkat pertama karena dalam pandangan mereka agama dan negara merupakan satu paket yang tidak terpisahkan. Premis ini berangkat dari nalar pemikiran yang mereka gulirkan yang bernuansa normatif dan formalistik. Nalar pemikiran Islamisme cenderung tekstual dan monotafsir dalam memaknai teks-teks Islam baik teks primer (al-Qur'an dan Hadis) maupun teks sekunder (pemikiran para ulama klasik). ${ }^{35}$ Kalangan Islamisme dalam doktrin dan ajarannya terkesan tidak appreciate terhadap pemaknaan Islam dari sisi historisitasnya. ${ }^{36}$

Islam dalam pemahaman kalangan ini adalah apa yang tertera dan termaktub secara tekstual-harfiah. Di luar itu dianggap sebagai sebuah distorsi pemaknaan terhadap Islam dan karenanya bukanlah makna Islam yang sebenarnya dan menyimpang. Keengganan mereka untuk melirik sisi kontekstual dan historisitas Islam yang selalu bersentuhan dan bergumul dengan dimensi kesejarahan ini pada akhirnya membuat tafsiran Islam ala Islamisme menjadi tercerabut dari nilai-nilai sosial kemanusiaan yang juga menjadi titik tekan dari ajaran Islam itu sendiri. ${ }^{37}$

Selain itu keengganan ini dipertajam dengan klaim penafsiran kebenaran tunggal (truth claim) dan wajah Islam yang tidak proporsional dalam menyikapi realitas sosial yang berkembang. Problem otoritas dan klaim kebenaran tunggal ini mengejawantah dalam wacana (discours) yang dipaksakan di ruang publik yang memang sarat dengan kontestasi ide dan gagasan keislaman. Pada perkembangan selanjutnya seringkali

\footnotetext{
${ }^{34}$ Hidayat dkk. Kontroversi Khilafah, 77.

35 Wahyu Setiawan dan Fredy Gandhi Midia. "Community acceptability to the Salafi movement". Akademika: Jurnal Pemikiran Islam 24, No. 02, July-Desember (2019), https://doi.org/10.32332/akademika.v24i2.1819

36 Amin Abdullah, Studi Agama Normativitas atau Historisitas? (Yogyakarta: Pustaka Pelajar, 2000), 12

${ }^{37}$ Amin Abdullah dkk. Mencari Islam Studi Islam dengan Berbagai Pendekatan (Yogyakarta: Tiara Wacana, 2000), 15.
}

Tribakti: Jurnal Pemikiran Keislaman

Volume 32, Nomor 1, Januari 2021 
otoritas tunggal atas nama agama ini mengarah pada tindakan anarkis, radikal, dan aksi teror yang mengemuka di berbagai negara yang diklaim sebagai negara kafir.

Pada ranah ini menjadi relevan tesis Khaled Abou el-Fadl yang menyatakan bahwa pemaksaan dan klaim kebenaran tunggal pada akhirnya menjadi sebuah konsep otoritarianisme $^{38}$ yang kontra produktif terhadap sistem pemaknaan dan penafsiran Islam yang sejatinya beragam dan multitafsir. Abou el-Fadl menjelaskan bahwa otoritarianisme adalah sebuah metodologi hermeneutika yang merampas dan menundukkan mekanisme pencarian makna dari sebuah teks ke dalam pembacaan yang sangat subyektif dan selektif. Subyektifitas yang selektif dari hermeneutika otoriter ini melibatkan penyamaan bahkan pengabaian terhadap realitas ontologis Tuhan dan pengambil alihan kehendak Tuhan oleh agen Tuhan sehingga agen tersebut secara efektif kemudian mengacu pada dirinya sendiri, dengan memandang maksud tekstual dan otonomi teks sebagai hal yang bersifat sekunder. ${ }^{39}$ Lebih jauh lagi Abou el-Fadl menjelaskan bahwa seorang pembaca yang subyektif pasti akan melakukan kesalahan penafsiran atau kecurangan dan melanggar syarat-syarat yang lain. ${ }^{40}$ Dengan penafsiran tunggal atas realitas sosial keagamaan yang sejatinya plural dan beragam ini menjadikan output tafsir yang mereka tawarkan sangat sempit dan rigid. Dunia dalam proyeksi kalangan Islamisme seakan-akan terbelah menjadi dua bagian yang saling menegasikan. Realitas sosial kemanusiaan hanya sebatas hitam putih, mukmin-kafir, Islam-non Islam, jahiliyah-Islam, Barat-Islam, dan seterusnya. ${ }^{41}$

Model penafsiran versi kalangan Islamisme tersebut jika ditelisik lebih dalam pada akhirnya bermetamorfosa menjadi "bahasa agama" yang cenderung menolak dan mengeksekusi penafsiran lainnya. Padahal menurut Mukhsin Jamil "bahasa agama" dapat didefinisikan dengan dua pendekatan yaitu theo oriented dan antropo oriented. Pertama, theo oriented adalah kalam Ilahi yang kemudian diabadikan atau terabadikan dalam kitab suci. Dalam pengertian ini Tuhan dan kalam-Nya lebih ditekankan, sehingga pengertian bahasa agama yang paling mendasar adalah bahasa kitab suci; kedua, antropo oriented adalah ungkapan serta perilaku keagamaan dari seseorang atau sebuah kelompok sosial. Jadi bahasa agama dalam pengertian kedua adalah wacana

38 M. Arfan Mu'ammar, Abdul Wahid Hasan dkk. Studi Islam Perspektif Insider/Outsider (Yogyakarta: IRCiSoD, 2014), 176.

${ }^{39}$ Kurdi dkk, Hermeneutika Al-Qur'an dan Hadis (Yogyakarta: eLSAQ-Press, 2010), 272-273.

${ }^{40}$ Khaled M. Abou el-Fadl, Atas Nama Tuhan Dari Fiqih Otoriter ke Fiqih Otoritatif, Terjemahan oleh R. Cecep Lukman Yasin (Jakarta: PT Serambi Ilmu Semesta, 2014), hlm. 16.

41 Zakiyuddin Baidhawy, Ambivalensi Agama Konflik dan Nirkekerasan (Yogyakarta: Lesfi, 2002), 182-199. 
keagamaan yang dilakukan oleh umat beragama maupun sarjana agama, meskipun tidak selalu merujuk serta menggunakan ungkapan-ungkapan kitab suci. ${ }^{42}$

Apabila dikaitkan dengan Islam, menurut Nashr Hamid Abu Zaid, maka dalam memahami pengertian bahasa agama, terdapat tiga bidang kajian yang mesti dibedakan; yakni, pertama, teks orisinal Islam (al-Qur'an dan Hadis); kedua, pemikiran Islam yang dianggap sebagai bentuk interpretasi atas teks orisinal yang dapat ditemukan dalam empat disiplin pokok wacana Islam yakni hukum, teologi, filsafat dan tasawuf; ketiga, perwujudan dan praktik sosio-politik Islam dalam masyarakat muslim dengan latar belakang sosio-historis yang berbeda-beda. ${ }^{43}$

\section{Tabel 3}

\section{Bahasa Agama dalam perspektif Nashr Hamid Abu Zaid ${ }^{44}$}

\begin{tabular}{ll}
\hline \multicolumn{2}{c}{ Bahasa Agama versi Nashr Hamid Abu Zaid } \\
\hline Teks Orisinal/primer & $\begin{array}{l}\text { Al-Qur'an dan } \\
\text { al-Hadis }\end{array}$ \\
& pemikiran Islam \\
feks Sekunder & fiqih, teologi, filsafat dan tasawuf \\
praktik sosial-historis umat Islam & konteks global: Islam transnasional (Ikhwan al-Muslimin dan \\
& Hizb al-Tahrir) \\
& Islam mainstream Indonesia (Nahdlatul Ulama, \\
& Muhammadiyah, Persis, Hizb al-Tahrir Indonesia, FPI, dan \\
& lain-lain) \\
\hline
\end{tabular}

Dalam konteks ini konsep yang digagas Sayyid Qutb adalah contoh yang popular. Qutb menggagas ide tentang hakimiyat Allah (pemerintahan Tuhan) atau nizam alRabbani (perundang-undangan Tuhan). Bagi Qutb, Islam harus menjadi landasan dalam bernegara dan karenanya secara formal Islam menjadi konstitusi yang wajib diwujudkan

42 M. Mukhsin Jamil, Revitalisasi Islam Kultural [Arus Baru Relasi Agama dan Negara] (Semarang: Walisongo Press, 2009), 213.

${ }^{43}$ M. Mukhsin Jamil, Revitalisasi Islam, 213.

${ }^{44}$ Format tabel merupakan olahan penulis berdasarkan beberapa karya berikut: (1) M. Mukhsin Jamil, Revitalisasi Islam Kultural [Arus Baru Relasi Agama dan Negara] (Semarang: Walisongo Press, 2009), (2) Moh. Shofan, Jalan Ketiga Pemikiran Islam Mencari Solusi Perdebatan Tradisionalisme dan Liberalisme (Yogyakarta: IRCiSoD-Universitas Muhammadiyah Gresik, 2006), (3) Nasr Hamid Abu Zayd, Dekonstruksi Gender Kritik Wacana Perempuan dalam Islam terjemahan oleh Moch. Nur Ichwan dan Moch. Syamsul Hadi (Yogyakarta: SAMHA-PSW IAIN SUKA dan McGill, 2003), dan (4) Nashr Hamid Abu Zaid, Hermeneutika Inklusif Mengatasi Problematika Bacaan dan Cara-Cara Pentakwilan atas Diskursus Keagamaan terjemahan oleh Muhammad Mansur dan Khoiron Nahdliyin (Jakarta: ICIPTAF, 2004).

Tribakti: Jurnal Pemikiran Keislaman

Volume 32, Nomor 1, Januari 2021 
eksistensinya di bumi ini. ${ }^{45}$ Bahkan Qutb melegitimasi perjuangan kekerasan dalam membentuk negara Islam adalah sah atau diperbolehkan. ${ }^{46}$ Qutb menyebut peradaban Barat atau Eropa modern sebagai jahiliyah, dalam arti barbar dan materialistis. Sebuah era atau zaman yang membawa nilai-nilai destruktif terhadap Islam dan umat Muslim. ${ }^{47}$ Modernisasi dan seluruh gagasannya seperti sekularisasi, nasionalisme, dan demokrasi adalah nilai-nilai jahiliyah yang harus digantikan dengan ideologi Islam. ${ }^{48}$ Demokrasi, misalnya, merupakan sistem kufur yang harus dilenyapkan dan digantikan dengan sistem negara Islam (khilafah Islamiyah). Negara Islam versi siapa yang diajukan Qutb memang masih menjadi persoalan dan pencarian format yang tepat oleh kalangan Islamisme. Khilafah Islam bagi kalangan Islamisme menjadi semacam romantisme dan nostalgia sejarah ${ }^{49}$ yang wajib ditegakkan jika umat Islam tidak ingin selalu dalam posisi tertindas, terbelakang dan akrab dengan kemiskinan dan kebodohan.

Dalam pandangan Qutb, demokrasi yang bertumpu pada kekuasaan rakyat sangat jelas dan terang-terangan telah menafikan kekuasaan Tuhan. Demokrasi telah mengubur dimensi tauhid Islam dengan kompromi suara rakyat yang seringkali dengan mudahnya dimanipulasi oleh pihak-pihak tertentu demi keuntungan pribadi dan golongan. ${ }^{50}$ Modernitas Barat yang menawarkan nilai-nilai baru dan bercorak materialistik dalam

45 Anton Minardi, “The New Revivalism in Indonesia: Accommodationist and Confrontationist”. Journal of Indonesian Islam 12, No 02, (Desember 2018), (http://jiis.uinsby.ac.id/index.php/JIIs/issue/view/25

${ }^{46}$ Ali Munhanif dan M. Dahlan, "Lineages of Islamic Extremism in Egypt: Ikhwan alMuslimun, State Violence and the Origins of Radical Politics (1923-1981) Al-Jāmi 'ah: Journal of Islamic Studies 57, No. 1, (2019 M/1440 H), 10.14421/ajis.2018.562.421-460

47 Abu Zahra (ed.), Politik Demi Tuhan Nasionalisme Religius di Indonesia (Bandung: Pustaka Hidayah, 1999), 151.

48 Robitul Firdaus. 'Nasionalisme 'Jalan Tengah': Mengurai Potensi Benturan Ideologi Nasionalisme dan Sentimen Ummah di Era Nation State”. Akademika: Jurnal Pemikiran Islam 23, No. 02 Juli-Desember (2018), http://dx.doi.org/10.32332/akademika.v23i2.1109288

${ }^{49}$ Berbagai upaya restorasi khilafah telah banyak dilakukan, tetapi berakhir dengan kegagalan. Di Mesir Jamaluddin al-Afghani (w. 1897 M) telah berupaya melalui Pan-Islamisme dan Rashid Ridha melalui Khilafah Darurat. Di India, Muhammad Ali dan Syaukat Ali membangun Khilafat Movement pada 1919 M. Di Nusantara SI Putih pimpinan HOS Cokroaminoto membentuk Central Committee Chilafat pada 1924 M. Akhirnya di Palestina Taqiyuddin al-Nabhani membentuk Hizb al-Tahrir pada 1952 M. Semua upaya itu gagal membangunkan kembali khilafah. Upaya lain melalui pembentukan lembaga transnasional seperti Organization of the Islamic Conference (OKI, Organisasi Konferensi Islam) dan melalui peningkatan semangat Pan Islam dalam dakwah oleh oraganisasi seperti Rabithah Alam Islami (Muslim World Legue), tidak juga membuahkan restorasi Khilafah. Lihat Abdul Aziz, Kontroversi Khilafah (Yogyakarta: LKiS, 2019), 212.

${ }^{50}$ Forum Kajian Ilmiah AFKAR, Kritik Ideologi Radikal Deradikalisasi Doktrin Keagamaan Ekstrem dalam Upaya Meneguhkan Islam Berwawasan Kebangsaan (Kediri: Lirboyo Press, 2019), 267268. 
pandangan pengusung konsep khilafah merupakan sebuah tatanan yang merusak, destruktif, jahiliyah dan harus digantikan dengan tatanan dunia baru, negara Islam. ${ }^{51}$

Model tafsir Qutb seperti itu dalam titik tertentu dapat menjelma menjadi "bahasa agama" yang disakralkan. Selain itu tafsir tersebut termasuk dalam level pemikiran Islam dan praktik sosial Islam, dan bukanlah "teks orisinal” Islam. Dikatakan pemikiran Islam karena teks itu berangkat dari tafsir Qutb atas realitas sosial Islam di Mesir yang terkait dengan berbagai setting sosial yang melingkupinya. Dan dikatakan praktik sosial Islam dikarenakan Qutb sendiri adalah cendekiawan muslim yang menjadi ikon dari organisasi Ikhwan al-Muslimin di Mesir. Di samping Qutb, ada al-Maududi yang merupakan mentornya dalam menafsirkan Islam secara tekstual dan normatif. AlMaududi yang merupakan pendiri Jamaah al-Islamiyah di Pakistan menggerakkan umat Islam untuk membentuk negara Islam yang lepas dari India yang mayoritas dikuasai oleh umat Hindu. Mirip dengan ide Qutb, ia menyatakan bahwa era modern adalah era jahiliyyah yang harus dimusnahkan dan diganti dengan era Islamiyah. Dengan konsep kedaulatan Tuhan (al-Hakimiyyah-al-Ilahiyyah) ia berupaya menggusur konsep demokrasi yang bersumber dari kedaulatan rakyat (al-Hakimiyyah al-Basyariyyah). ${ }^{52}$

\section{Tabel 4}

\section{Nalar Pemikiran Gerakan Islamisme53}

\begin{tabular}{ll}
\hline & Nalar Pemikiran Gerakan Islamisme \\
\hline Nalar Islamisme & Tekstual-nomatif/legal-formalistik \\
Metode pemikiran & Dialektik-dikotomik \\
Diskursus & Khilafah Islamiyah, kewajiban berhijab, demokrasi sistem \\
keagamaan & kufur, dan jihad kombatif \\
\hline
\end{tabular}

Berbeda dengan tesis dari kalangan Islamisme di atas. Penafsiran agak moderat ditampilkan oleh beberapa cendekiawan muslim yang pada awalnya berada dalam gerbong Islamisme. Beberapa nama yang dapat disebut misalnya Abdul Karim Sorosh dari Iran, dan Hassan Hanafi dari Mesir. Salah satu alasan mengapa mereka dimasukkan dalam gerbong Pos-Islamisme adalah karena keterbukaan paradigma berpikir mereka

${ }^{51}$ Muhammad Tisna Nugraha. "Fundamentalisme Pendidikan Agama di Jejaring Sosial". AlTahrir: Jurnal Pemikiran Islam 18, No. 1 (2018), https://doi.org/10.21154/altahrir.v18i1.1172

52 Bayat, Pos-Islamisme, 99-104. Mahmoud Sadri dan Ahmad Sadri (eds.), Abdul Karim Soroush Menggugat Otoritas, 208-212.

${ }^{53}$ Format tabel merupakan olahan penulis berdasarkan beberapa karya Aksin Wijaya seperti (1) Dari Membela Tuhan ke Membela Manusia Kritik atas Nalar Agamaisasi Kekerasan, (2) Kontestasi Merebut Kebenaran Islam di Indonesia dari Beislam secara Teologis ke Berislam secara Humanis, dan (3) Ragam Jalan Memahami Islam Panorama Sejarah, Dinamika Paradigma, dan Kontestasinya. 
yang berani keluar dari pakem dan tatanan pemikiran tradisional-konservatif kalangan Islamisme. Mereka tidak hanya berkutat dalam tradisi pemikiran para ulama klasik (turath), tetapi juga berani berdialog dengan pemikiran-pemikiran modern Barat yang membawa ide dan konsep tentang kebebasan, kesetaraan, dan kemanusiaan.

Abdul Karim Sorosh misalnya dikenal sebagai cendekiawan muslim liberal Iran yang berupaya untuk mencari terobosan tentang bentuk sistem pemerintahan yang relevan dengan kondisi kekinian pasca revolusi Islam Iran. ${ }^{54}$ Menurutnya sistem pemerintahan Republik Islam Iran yang terlalu tertutup dari dunia luar kontraproduktif dengan realitas sosial kontemporer. Realitas sosial kekinian adalah era keterbukaan dan kebebasan. Privatisasi peran perempuan misalnya dia nilai absurd dan bukanlah ajaran yang berasal dari Islam. Laki-laki dan perempuan memiliki ruang yang sama di ranah publik. ${ }^{55}$ Keduanya mempunyai hak dan kewajiban yang sama untuk menentukan masa depan Iran ke depannya. Sorosh sangat kritis dengan model kepemimpinan wilayat alfaqih $^{56}$ yang digagas oleh Ayatollah Khomeini di era Revolusi Iran pada 1970-an di mana pemerintahan didominasi oleh para ahli fiqih dengan pemikiran konservatismenya yang tertutup dengan pembaruan pemikiran keagamaan.

Sementara itu Hassan Hanafi merupakan cendekiawan kontemporer yang bergelut dengan perkembangan pemikiran Mesir modern. Gagasannya yang terkenal "Islam Kiri” (al-Yasar al-Islami), revitalisasi tradisi (turath) dan Oksidentalisme (al-Istighrab) menyasar pemikiran Islamisme Ikhwan al-Muslimin yang hanya berkutat di wilayah pemikiran Islam klasik. Mega proyek besar Hanafi tersebut adalah upayanya dalam merekonstruksi seluruh bangunan keilmuan Islam yang dirasanya tidak bersentuhan sama sekali dengan realitas sosial umat Islam yang kini dalam posisi inferior di hadapan hegemoni peradaban Barat modern. Hanafi adalah potret perpaduan pemikiran dua peradaban besar, Islam dan Barat.

Menurut M. Aunul Abied Shah dalam konteks pembaruan pemikiran keislaman, secara polaritatif terdapat dua aliran pemikiran besar yang sama-sama menuju pada pencerahan Islam, yaitu, pertama, kelompok Islamisme, dan kedua, kelompok sekularisme. Kelompok pertama mewakili kelompok militan-fundamental yang meyakini bahwa kebesaran umat Islam tergantung pada kesadaran mereka dalam

${ }^{54}$ Mahmoud Sadri dan Ahmad Sadri (eds.), Abdul Karim Soroush Menggugat Otoritas, hlm. 177184.

${ }^{55}$ Bayat, Pos-Islamisme, 138-145.

${ }^{56}$ Nurkhalis. "Representasi Khilafah Dalam Pemerintahan Republik Spiritual”. Akademika: Jurnal Pemikiran Islam 23 No. 02, Juli-Desember (2018), http://dx.doi.org/10.32332/akademika.v23i2.1109288 
melaksanakan ajaran agamanya dengan kembali pada ajaran inti al-Qur'an dan Sunnah sebagai penekanannya. Sementara kelompok kedua mewakili kelompok reformismodernis yang meyakini bahwa Islam adalah agama hadlari (peradaban), yang karenanya harus terbuka terhadap unsur-unsur peradaban lain. Untuk itu, ajaran Islam mesti diaktualisasikan dan diperbarui, dengan mencoba upaya redefinisi, agar senantiasa relevan dengan perkembangan zaman. ${ }^{57}$

Tabel 5

Nalar Pemikiran Gerakan Pos-Islamisme ${ }^{58}$

\begin{tabular}{ll}
\hline \multicolumn{2}{c}{ Nalar Pemikiran Gerakan Pos-Islamisme } \\
\hline Nalar Pos Islamisme & kontekstual-historis/pluralis-substansialistik \\
Metode pemikiran & dialektik-pluralis \\
Diskursus & tradisi versus kebebasan, otoritas Tuhan versus otoritas \\
keagamaan & manusia, otoritas ulama versus otoritas individual, dan \\
& wilayat al-faqih versus demokrasi \\
\hline
\end{tabular}

\section{Paradigma Pemikiran Islam Transnasional}

Dari wacana yang dikembangkan kalangan Islamisme di atas terdapat ketidakberimbangan dalam menempatkan posisi antara teks, akal, dan realitas kekinian. Ketidakberimbangan tersebut tercermin dari model penafsiran yang memiliki kecenderungan struktural dominatif oleh teks terhadap posisi akal dan realitas. Oleh karena itu menurut Rashid Khalidi diperlukan upaya deradikalisasi pemaknaan Islam yang relevan dengan kondisi zaman kekinian. Pemaknaan teks gaya Islamis yang cenderung tekstual-normatif perlu dideradikalisasi secara linguistik sehingga didapatkan tafsir yang humanis dan mencerahkan. ${ }^{59}$

Model tafsir kalangan Islamisme yang bernuansa struktural ini sejalan dengan paradigma tafsir klasik-tradisional yang menempatkan secara subordinatif posisi akal dan realitas di bawah kekuasaan teks. Penafsiran teks seperti ini cenderung rigid, kaku,

57 M. Aunul Abied Shah dkk, Islam Garda Depan Mosaik Pemikiran Islam Timur Tengah (Bandung: Mizan, 2000), 232-233.

${ }^{58}$ Format tabel merupakan olahan penulis berdasarkan beberapa karya Aksin Wijaya berikut: (1) Dari Membela Tuhan ke Membela Manusia Kritik atas Nalar Agamaisasi Kekerasan (Bandung: Mizan, 2017), (2) Kontestasi Merebut Kebenaran Islam di Indonesia dari Beislam secara Teologis ke Berislam secara Humanis (Yogyakarta: IRCiSoD, 2019), dan (3) Ragam Jalan Memahami Islam Panorama Sejarah, Dinamika Paradigma, dan Kontestasinya (Yogyakarta: IRCiSoD, 2019).

59 Widhiya Ninsiana, "Deradicalizing Religious Extremism Linguistically: An Intertextual Approach to Islamic Extremists' View on the Qur'anic Interpretation”. Akademika: Jurnal Pemikiran Islam 25, No 2, (2020), https://doi.org/10.32332/akademika.v25i2.2053

Tribakti: Jurnal Pemikiran Keislaman

Volume 32, Nomor 1, Januari 2021 
dan tercerabut dari realitas sosial kekinian yang tentu saja berbeda dengan konteks kemunculan teks di era klasik. ${ }^{60}$

Menurut Abdul Mustaqim posisi teks, akal, dan realitas dalam paradigma tafsir tradisional dapat digambarkan sebagai berikut: ${ }^{61}$

\section{Paradigma Struktural}

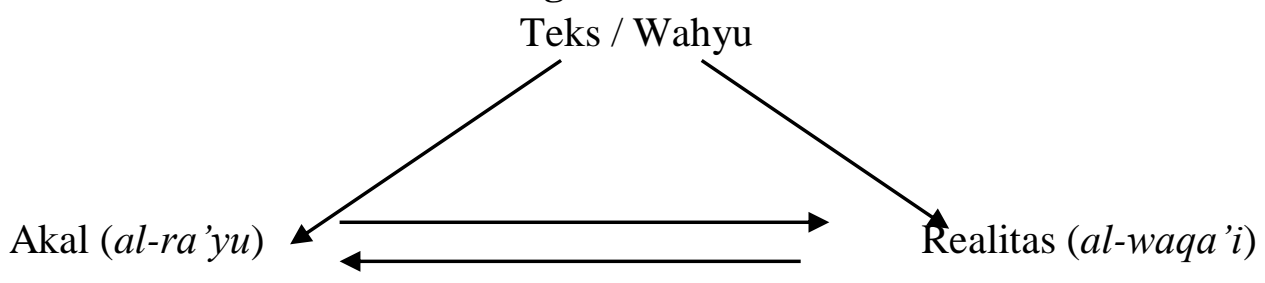

Sebaliknya, kalangan Pos-Islamisme mengembangkan model paradigma pemikiran yang lebih appreciate dan adaptif terhadap nilai-nilai modernitas yang datang dari Barat. Apresiasi dan penerimaan ide dan gagasan dari Barat ini terlihat dari model paradigma pemikiran yang ditawarkan oleh kalangan Pos-Islamisme. Jika dilihat dari sisi sumber penafsiran, model tradisi penafsiran yang dikembangkan kalangan PosIslamisme mengikuti pola penafsiran yang bersumber pada teks al-Qur'an (naș), akal (al-ijtihād), dan realitas empiris/social (al-wāqi'iyah). Secara paradigmatik posisi teks, akal, dan realitas ini berposisi sebagai objek dan subjek sekaligus. Ketiganya selalu berdialek secara sirkular dan triadic. Ada peran yang berimbang antara teks, pengarang, dan pembaca. Paradigma yang dipakai dalam memandang teks, akal, dan realitas adalah paradigma fungsional, bukan paradigma struktural yang cenderung saling menghegemoni dan menghakimi satu sama lain. ${ }^{62}$

Oleh karena itu posisi teks, akal, dan realitas dalam paradigma pemikiran kalangan Pos-Islamisme bisa dicermati pada skema di bawah ini: ${ }^{63}$

\section{Paradigma Fungsional}

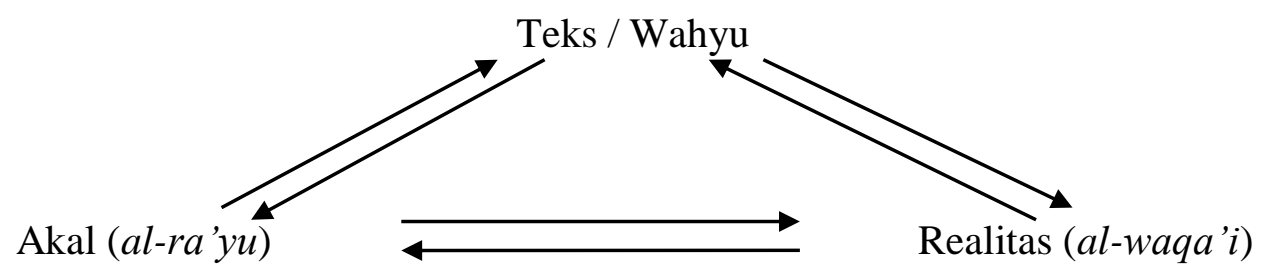

60 Huda, Miftahul. "Manhaj Fiqh Salafi-Literal Eksplorasi, Kritik, dan Apresiasi”. Ulumuna: Journal of Islamic Studies 19, No. 1, (2015), https://doi.org/10.20414/ujis.v19i1.1253

${ }^{61}$ Abdul Mustaqim, Epistemologi Tafsir Kontemporer (Yogyakarta: LKiS, 2010), 67.

62 Mustaqim.

${ }^{63}$ Mustaqim. 
Mengacu kepada dua model paradigma di atas, dan dari wacana yang digagas, pemikiran kalangan Pos-Islamisme dapat diposisikan pada paradigma kedua (fungsional). Jika paradigma pertama (struktural) dalam memandang realitas yang plural harus tunduk kepada teks yang diandaikan sebagai penafsir tunggal terhadap masalahmasalah kemanusiaan. Maka sebaliknya, paradigma kedua lebih menekankan dimensi dialektik-dialogis antara teks, akal, dan realitas sosio-historis dan karenanya ia peka dengan problematika kemanusiaan. Pada titik inilah, agama menjalankan visi transformatifnya untuk mengubah dan memecahkan persoalan-persoalan kemanusiaan kontemporer seperti relasi Islam dan negara, Islam dan demokrasi, sekularisme, liberalisme, pluralisme, kemiskinan, kebodohan, dan segala bentuk ketidakadilan di masyarakat.

Sementara paradigma kedua (struktural) dalam memandang realitas yang plural harus tunduk kepada teks yang diandaikan sebagai penafsir tunggal terhadap masalahmasalah kemanusiaan. Padahal sebagai agama yang bergumul dengan realitas, ia haruslah memiliki watak dinamis dan transformatif. Di sinilah paradigma kedua (fungsional) menawarkan corak dialogis antara ketiganya dalam mengapresiasi dan mencerna realitas empirik kemanusiaan yang plural dan bahkan multikultural pada saat ini.

Oleh karena itu, dalam menyikapi hal tersebut, gerakan Pos-Islamisme selalu berupaya menumbuhkembangakan berpikir kontekstual dan mengandalkan nalar kritis dalam memandang realitas kehidupan ini. Karena pada dasarnya, nalar kritis selalu diperlukan dalam mengawal perubahan yang menjadi misi dan visi transformatif agama dalam kehidupan ini. Nalar kritis yang dikembangkan oleh gerakan Pos-Islamisme dapat digambarkan dalam sebuah skema berikut ini: ${ }^{64}$

\section{Nalar Kritis Gerakan Pos-Islamisme}

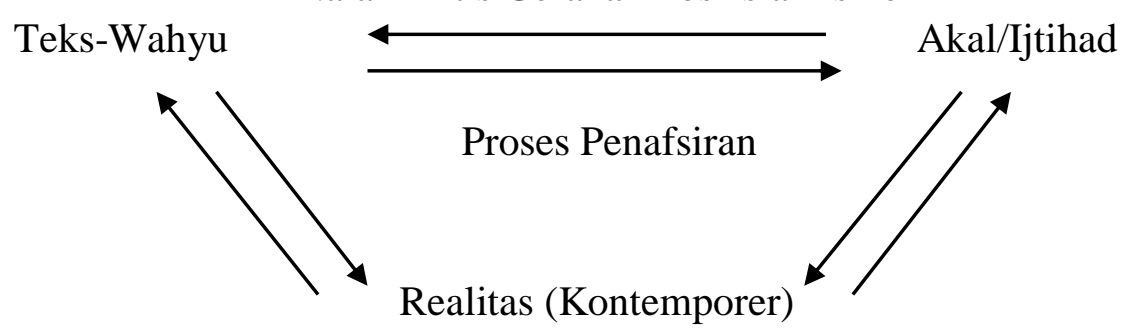

Dengan mengikuti nalar kritis gerakan Pos-Islamisme tersebut, pola penafsiran terhadap ajaran Islam akan terus mengalami perubahan seiring dengan perkembangan zaman. Karena setiap zaman memiliki ciri khas dan pola pikir yang berbeda antara satu

${ }^{64}$ Abdul Mustaqim, Epistemologi Tafsir, 130. 
dengan lainnya. Ibnu Rusyd dalam bukunya Bidāyah al-Mujtahid, menyatakan bahwa teks (text) adalah sesuatu yang terbatas (mutanāhiyah), sedangkan realitas (context) dan fenomena yang terjadi di masyarakat selalu mengalami dinamika dan perkembangan yang berkesinambungan secara terus menerus dan aktual (ghairu mutanāhiyah). ${ }^{65}$

\section{Kesimpulan}

Dari telaah historis dan paradigma pemikiran di atas terpapar dengan jelas pergeseran paradigma pemikiran yang diusung oleh kedua gerakan Islam tersebut. Gerakan Islamisme yang mengusung ide simbolisme agama dapat dikatakan merupakan embrio dari kemunculan gerakan Pos-Islamisme yang mengembangkan wacana posagama. Dalam hal ini Pos-Islamisme merupakan kontinuitas wacana dan gerakan dari kalangan Islamisme.

Diseminasi ide, gagasan, dan gerakan dari keduanya kian tak terbendung di era kontemporer ini. Pertarungan wacana dan gerakan masih berlangsung di era multikultural yang nota bene berada di luar jangkauan pemikiran kalangan Islamisme yang mengidolakan dan mengagendakan universalisme Islam dan menegasikan partikularitas kearifan lokal (local wisdom).

Dalam konteks negara bangsa Indonesia yang multikultural, persoalan ini menjadi pekerjaan rumah bersama anak bangsa untuk dapat menjembatani gap wacana dan gerakan di antara keduanya. Perjuangan yang sesungguhnya adalah memakmurkan peradaban dan bukan sebaliknya, menghancurkan dan menumpahkan darah antara sesama yang memang diciptakan dalam kondisi yang plural dan multikultural.

\section{Daftar Pustaka}

Abdullah, M. Amin. Multidisiplin, Interdisiplin, dan Transdisiplin Metode Studi Agama dan Studi Islam di Era Kontemporer. Yogyakarta: IB Pustaka PT Litera Cahaya Bangsa dan Pusat Studi Perubahan Sosial Universitas Muhammadiyah Surakarta, 2020.

Studi Agama Normativitas atau Historisitas? Yogyakarta: Pustaka Pelajar, 2000.

Mencari Islam Studi Islam dengan Berbagai Pendekatan. Yogyakarta: Tiara Wacana, 2000.

Abied Shah, M. Aunul et al, Islam Garda Depan Mosaik Pemikiran Islam Timur Tengah. Bandung: Mizan, 2000.

65 Abū Walīd Muḥammad Ibn Aḥmad Ibn Muḥammad Ibn Aḥmad Ibn Rusyd al-Qurțubī alAndalusī, Bidāyah al-Mujtahid wa Nihayah al-Muqtașid (Surabaya: al-Hidayah, Juz I, tt), 2. 
Abou El-Fadl, Khaleed M. Atas Nama Tuhan Dari Fiqih Otoriter ke Fiqih Otoritatif. Terjemahan oleh R. Cecep Lukman Yasin. Jakarta: PT Serambi Ilmu Semesta, 2014

Afrohah. "Fundamentalisme: Korelasi Ideologi Fundamentalis dengan Ideologi Gerakan Islam Modern”. Al-Tahrir 18, No. 1, 2018, https://doi.org/10.21154/altahrir.v18i1.1170

Al-Makin. "Tanggalkan Khalifah di Bumi Ini: Membaca Narasi Sukarno tentang Sekularisme Turki”. Al-Tahrir 16, No. 2, 2016, https://doi.org/10.21154/altahrir.v16i2.554

Asy Syaukani, Luthfi. Islam Benar versus Islam Salah. Jakarta: Kata Kita, 2007.

Azca, Muhammad Najib; Hakimul Ikhwan; Moh Zaki Arrobi. "A Tale of Two Royal Cities: The Narratives of Islamists' Intolerance in Yogyakarta and Solo". AlJāmi 'ah: Journal of Islamic Studies 57, No. 1, $(2019$ M/1440 H) doi: 10.14421/ajis.2018.562.421-460

Azra, Azyumardi. Transformasi Politik Islam Radikalisme, Khilafatisme, dan Demokrasi. Jakarta: Prenada Media Group, 2016.

Aziz, Abdul. Kontroversi Khilafah. Yogyakarta: LKiS, 2019.

Asef Bayat, Asef. Pos-Islamisme. Terjemahan oleh Faiz Tajul Milah Yogyakarta: LKiS, 2011.

M. Djidin dan Sahiron Syamsuddin, "Indonesian Interpretation of The Qur'an on Khilafah the Case of Quraish Shihab and Yudian Wahyudi on Qur'an 2: 30-38. Al-Jāmi 'ah: Journal of Islamic Studies 57, No. 1, (2019 M/1440 H), doi: 10.14421/ajis.2019.57

Eickelman, Dale F. dan Piscatori, James. Ekspresi Politik Muslim. Terjemahan oleh Rofik Suhud. Bandung: Mizan, 1998.

Fata, Ahmad Khoirul dan Moh Nur Ikhwan "Pertarungan Kuasa dalam Wacana Islam Nusantara". Islamica: Jurnal Studi Keislaman 11, No. 2, (2017), https://doi.org/10.21154/.v16i2.554

Forum Kajian Ilmiah AFKAR, Kritik Ideologi Radikal Deradikalisasi Doktrin Keagamaan Ekstrem dalam Upaya Meneguhkan Islam Berwawasan Kebangsaan. Kediri: Lirboyo Press, 2019.

Firdaus. Robitul. 'Nasionalisme 'Jalan Tengah': Mengurai Potensi Benturan Ideologi Nasionalisme dan Sentimen Ummah di Era Nation State". Akademika: Jurnal Pemikiran Islam 23, No. 02, Juli-Desember (2018), http://dx.doi.org/10.32332/akademika.v23i2.1109288

Halim, Abd. Relasi Islam Politik dan Kekuasaan. Yogyakarta: LKiS, 2013.

Hilmy, Masdar. "Akar-akar Transnasionalisme Islam Hizbut Tahrir Indonesia (HTI)". Islamica: 6, No. 1, (2011)

Hidayat, Komaruddin. (ed). Kontroversi Khilafah Islam, Negara dan Pancasila. Bandung: Mizan, 2014. 
Huda, Miftahul. "Manhaj Fiqh Salafi-Literal Eksplorasi, Kritik, dan Apresiasi". Ulumuna: Journal of Islamic Studies 19 No. 1, (2015), https://doi.org/10.20414/ujis.v19i1.1253

Husni, Zainul Mu'ien. "NU di Tengah Pusaran Ideologi-Ideologi Transnasional". Jurnal Islam Nusantara 02, No. 01, Januari - Juni (2018)

Ibn Rusyd, Abu Walid Muhammad Ahmad Ibn Muhammad Ibn Ahmad al-Qurtubi alAndalusi. Tanpa Tahun. Bidayah al-Mujtahid wa Nihayah al-Muqtasid. Surabaya: al-Hidāyah, tt.

Jahroni, Jajang. "Saudi Arabia Charity and the Institutionalization of Indonesian Salafism". Al-Jāmi 'ah: Journal of Islamic Studies 58, No. 1, 2020 M/1441 H), doi: https://doi.org/10.14421/ajis.2018.562.421-460

Jamil, M. Mukhsin. Revitalisasi Islam Kultural [Arus Baru Relasi Agama dan Negara]. Semarang: Walisongo Press, 2009.

Minardi, Anton. "The New Revivalism in Indonesia Accommodationist and Confrontationist". Journal of Indonesian Islam 12, No 02, (Desember 2018), http://jiis.uinsby.ac.id/index.php/JIIs/issue/view/25

Mu'ammar, M. Arfan dan Hasan Abdul Wahid dkk. Studi Islam Perspektif Insider/Outsider. Yogyakarta: IRCiSoD, 2014.

Munhanif, Ali dan M. Dahlan, "Lineages of Islamic Extremism in Egypt: Ikhwan alMuslimun, State Violence and the Origins of Radical Politics (1923-1981) Al-

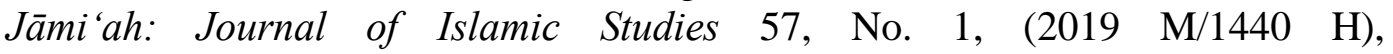
10.14421/ajis.2018.562.421-460

Mustaqim, Abdul. Epistemologi Tafsir Kontemporer, Yogyakarta: LKiS, 2010.

Ninsiana, Widhiya "Deradicalizing Religious Extremism Linguistically: An Intertextual Approach to Islamic Extremists' View on the Qur'anic Interpretation". Akademika: Jurnal Pemikiran Islam 25, No 2, (2020), https://doi.org/10.32332/akademika.v25i2.2053

Nugraha, Muhammad Tisna. "Fundamentalisme Pendidikan Agama di Jejaring Sosial". Al-Tahrir: Jurnal Pemikiran Islam 18, No. 1, (2018), 10.21154/altahrir.v18i1.1172, diakses 3 Desember 2020).

Nurkhalis. "Representasi Khilafah Dalam Pemerintahan Republik Spiritual". Akademika: Jurnal Pemikiran Islam 23, No. 02, Juli-Desember (2018), http://dx.doi.org/10.32332/akademika.v23i2.1109288

Qomar, Mujamil. Fajar Baru Islam Indonesia? Kajian Komprehensif atas Arah Sejarah dan Dinamika Intelektual Islam Nusantara, Bandung: Mizan, 2012.

Redjosari, Slamet Muliono. "Salafi dan Stigma Sesat-Radikal". Islamica: Jurnal Studi Keislaman 13, Nomor 2, Maret (2019), https://doi.org/10.21154/.v16i2.554 
Ridwan Rosdiawan, "Memetakan Anatomi Diskursus Islamisme dan Terorisme Islam". Islamica: Jurnal Studi Keislaman 13, No. $1 . \quad$ (2018), https://doi.org/10.21154/.v16i2.554

Santoso, Thomas. Kekerasan Agama Tanpa Agama, Jakarta: Pustaka Utan Kayu, 2002.

Setiawan, Wahyu dan Fredy Gandhi Midia. "Community acceptability to the Salafi movement". Akademika: Jurnal Pemikiran Islam 24, No. 02, July-Desember (2019), https://doi.org/10.32332/akademika.v24i2.1819

Tibi, Bassam. Islam dan Islamisme. Terjemahan oleh Alfathri Adlin. Bandung: Mizan, 2016.

Yakin, Ayang Utriza. "Salafi Dakwah and the Dissemination of Islamic Puritanism in Indonesia: A Case Study of the Radio of Rodja". Ulumuna: Journal of Islamic Studies 22, No. 2 (2018), https://doi.org/10.20414/ujis.v22i2.335

Wahid, Abdurrahman. Abdurrahman Wahid (Ed.). Ilusi Negara Islam Ekspansi Gerakan Islam Transnasional di Indonesia. Jakarta: Gerakan Bhinneka Tunggal Ika-The Wahid Institute-Maarif Institute, 2009.

Abu Zahra, Abu. (ed.). Politik Demi Tuhan Nasionalisme Religius di Indonesia. Bandung: Pustaka Hidayah, 1999. 